Kansas State University Libraries

New Prairie Press

Kansas State University Undergraduate

Research Conference

Spring 2019

\title{
Characterization of a Membrane-Bound Insect Transferrin
}

Diana Najera

Follow this and additional works at: https://newprairiepress.org/ksuugradresearch

Part of the Biochemistry Commons

(c) (i) (9)

This work is licensed under a Creative Commons Attribution-Noncommercial 4.0 License

\section{Recommended Citation}

Najera, Diana (2019). "Characterization of a Membrane-Bound Insect Transferrin," Kansas State University Undergraduate Research Conference. https://newprairiepress.org/ksuugradresearch/2019/posters/51

This Event is brought to you for free and open access by the Conferences at New Prairie Press. It has been accepted for inclusion in Kansas State University Undergraduate Research Conference by an authorized administrator of New Prairie Press. For more information, please contact cads@k-state.edu. 


\section{Characterization of a Membrane-Bound Insect Transferrin}

Diana G. Najera, Michelle E. Coca, Kayla E. Nutsch, Maureen J. Gorman Department of Biochemistry and Molecular Biophysics

Kansas State University

\section{Abstract}

Transferrins are extracellular proteins that bind on. Vertebrate transferrins have well-characterized roles in iron ransport and immunity, but the functions of transferrins in most other animals are poorly understood. The goals of this study are to identify the functions of transferrin-3 (Tsf3) from Drosophila other species of insects. Our experimental approach has been to predict important features of the protein, analyze gene expression, perform RNAi-mediated knockdown in cultured cells, and use phylogenetic analysis to identify Tsf3 orthologs. An analysis nd anchored to the plasma membrane. Putative iron-binding residues are present in the carboxyl-lobe, but iron-binding residues appear to be lacking in the amino-lobe; therefore, we predict that only the carboxyl-lobe binds iron. Tsf3 is expressed at low level throughout development in many tissues, but it is very highly expressed in prepupal salivary glands. Cells of the prepupa salivary glands are exceptional because of their extensive DNA replication and because they synthesize large amounts of glue proteins that are used by the insect to attach isself to a solid surface pror to pupation. Hgh expression tri Ts 3 in the prepupal salvary in these glands, possibly to be used as a cofactor for enzymes equired for DNA synthesis, or perhaps to be used in the glue biosynthesis process. To test the hypothesis that Tsf3 is used for on uptake by insect cells, we are in the process of evaluating the ffect of RNAi-mediated knockdown of Tsf3 on cellular iron content. Toward this goal, we verified that Tsß is expressed in

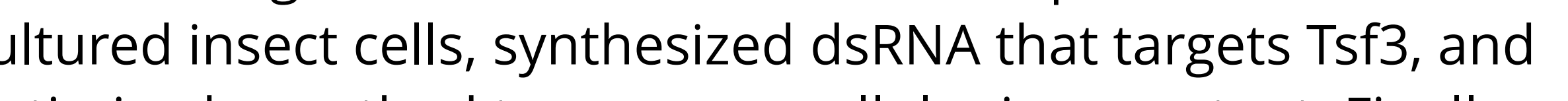
aptimized a method to measure cellular iron content. Finally, we did a a bound, iron-binding protein that may be involved in cellular iron uptake in diverse species of insects.

\section{Transferrin 3 Amino Acid Sequence}

Prediction of the signal peptide, transmembrane region, and iron binding residues.

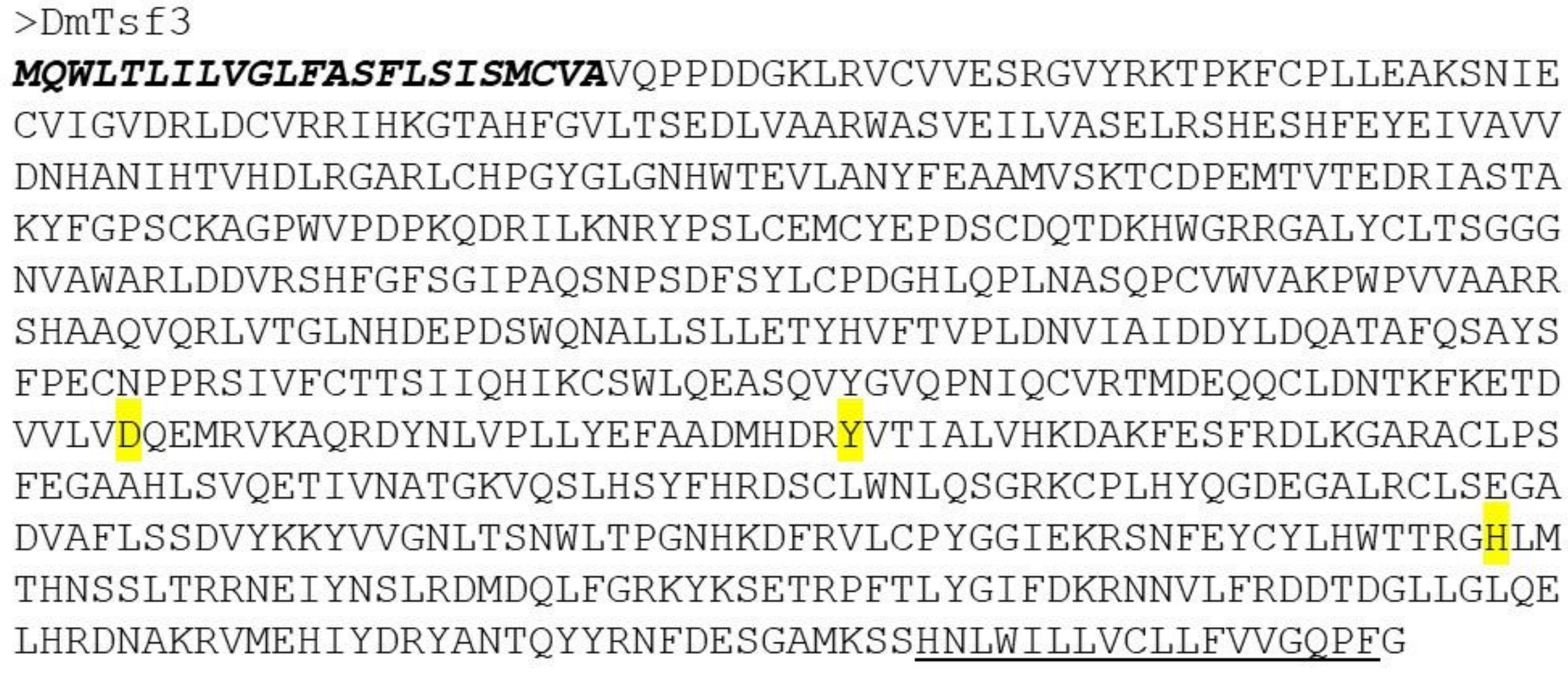

Signal P predicts a signal peptide, in bold, with a cleavage site at CVA-VQ. TMPred predicts a C-termina

transmembrane region, which is HNLWILLVCLLFVVGQPFG. The amino acids highlighted in yellow are predicted to be iron binding.

\section{Expression of Transferrin 3}

This graph from Flybase shows the expression of Tsf3 in different tissues, during different developmental stages of different tissues,
D. melanogaster.

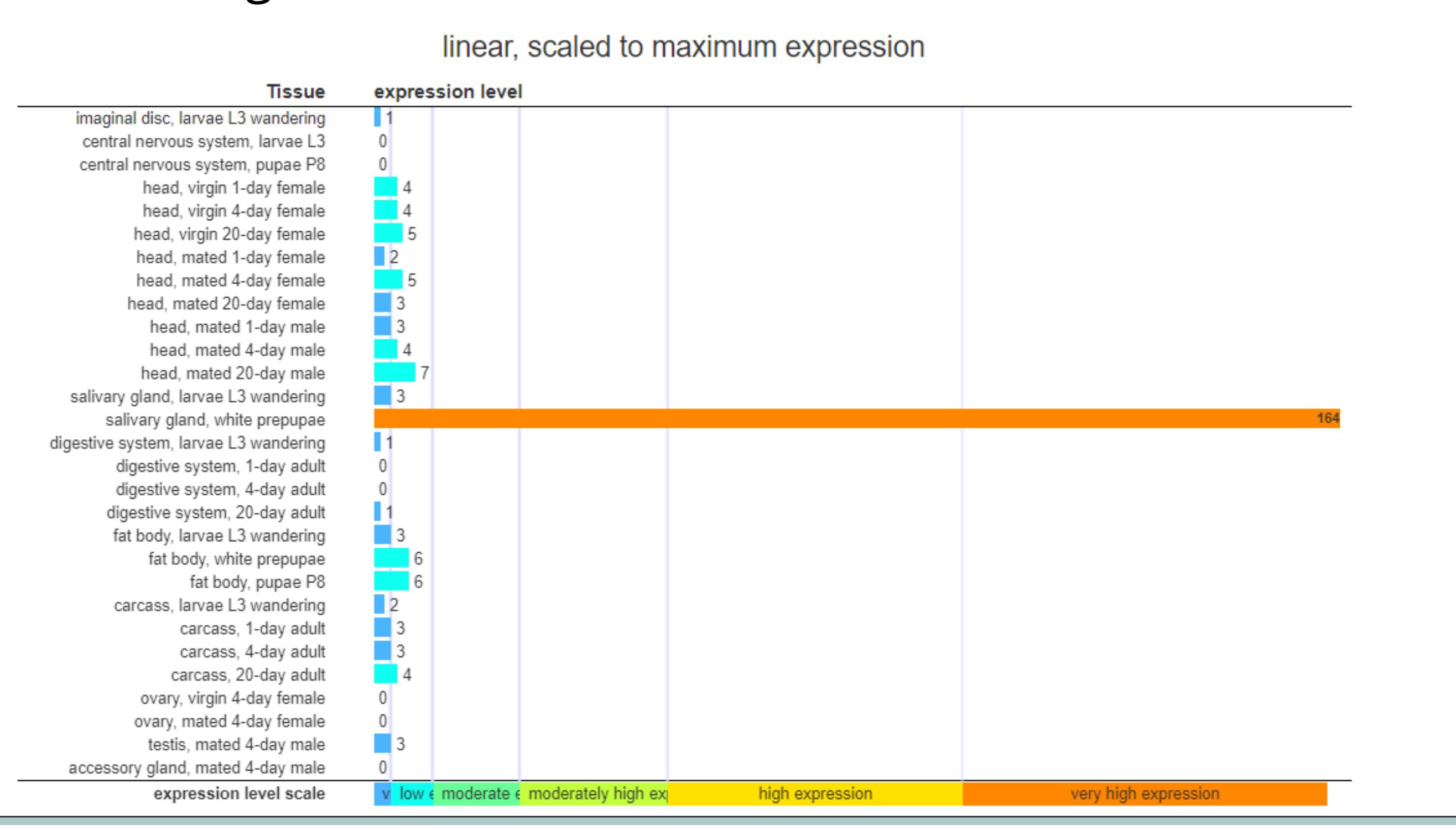

- Tsf3 is expressed in many different tissues of $D$. melanogaster.

Tsf3 is expressed through all the developmenta tages of D. melanogaster.

This suggests that Tsf3 expression is consisten with iron uptake throughout $D$. melanogaster. White prepupae have the highest expression out of all stages in development.

The salivary gland in white prepupae has the highest expression when compared to other tissues

in $D$. melanogaster.

At the white prepupae stage large amounts of glue proteins are being produced. If this process requires iron:

\section{Sg4 Cells Express Transferrin 3}

We want to study the function of Tsf3 in cultured $D$. melanogaster cells. We did RNA isolation, CDNA synthesis, PCR and agarose ge

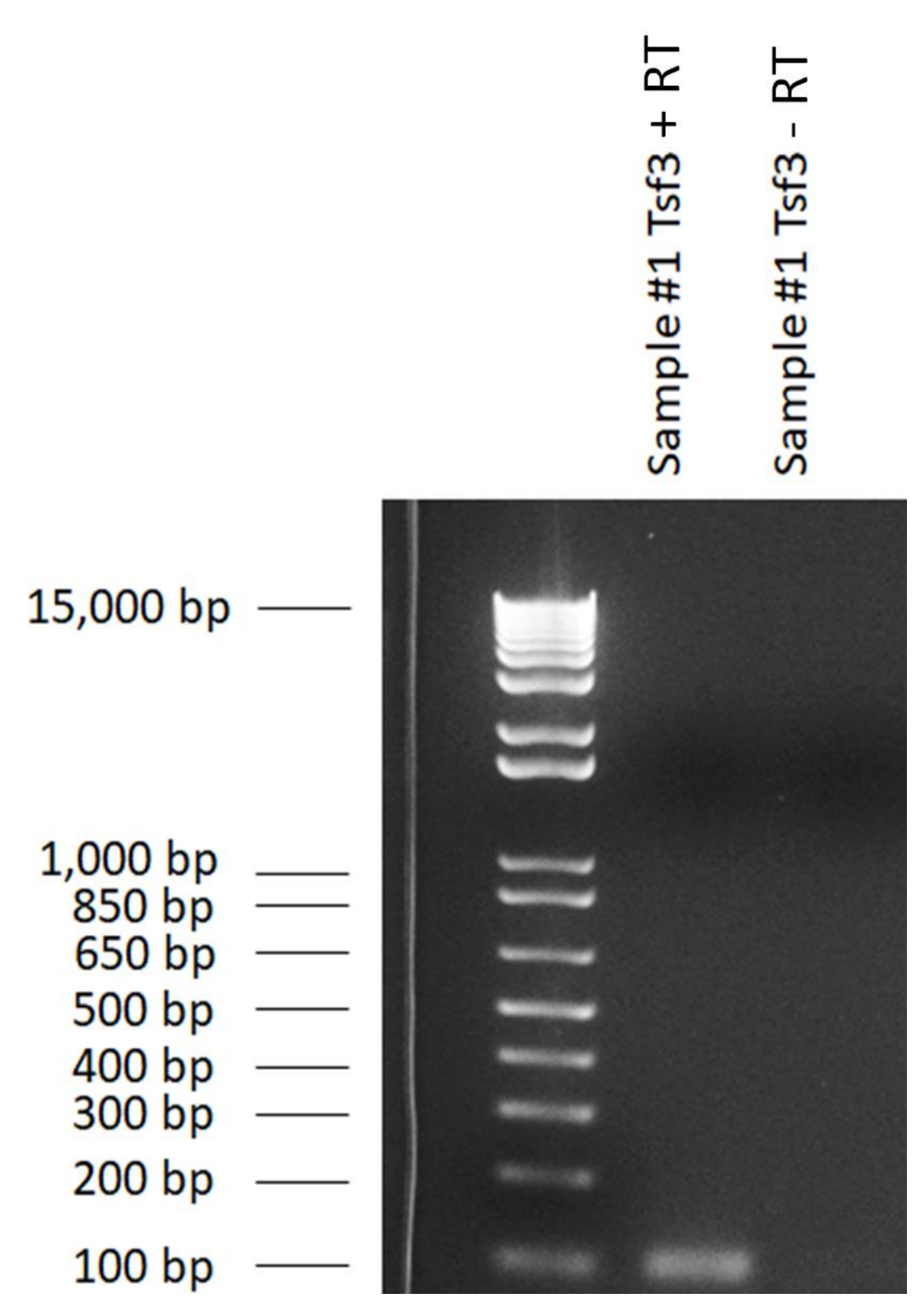

The sample with reverse transcriptase and Tsf3 primers showed a band at the expected size of $103 \mathrm{bp}$. The comparable sample without reverse transcriptase did not have a band at a larger size (372 bp), which confirmed that there was no genomic DNA contamination in the samples. These results demonstrate that Sg4 cells express Tsf3.

\section{Knockdown of Transferrin 3}

We want to study the effect of insufficient Tsf3 in the g4 cells. We did RNA interference, RNA isolation, determine if Tsf 3 was knocked down

successfully. Gapdh was used as the reference gene.

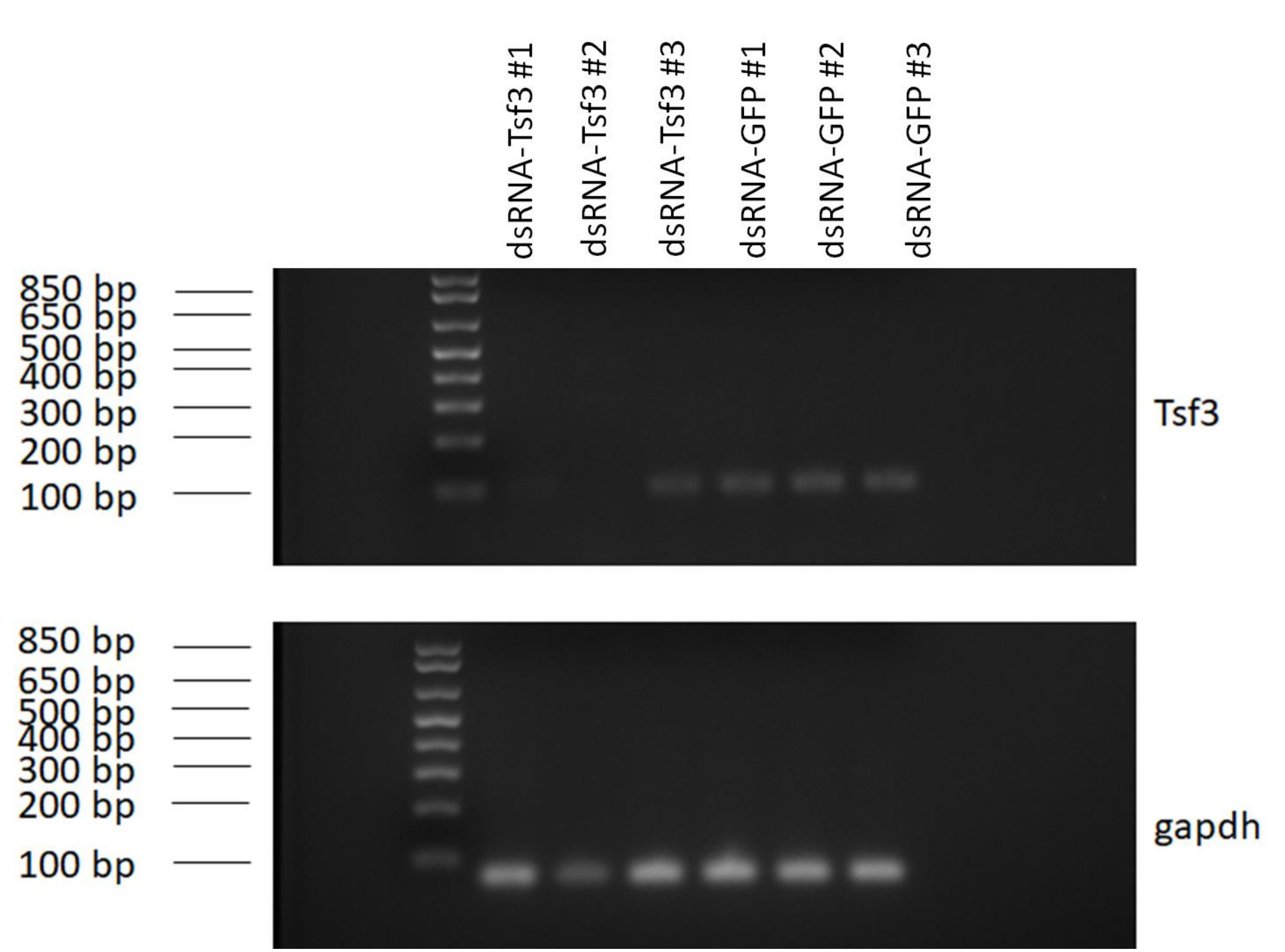

Two out of three samples treated with dsRNA-Tsf3 had strong knockdown and one sample had weak knockdown suggesting that knockdown efficiency varies between each

Phylogenetic Analysis of Insect Transferrins

We wanted to determine if other insects had Tsf3 orthologs.

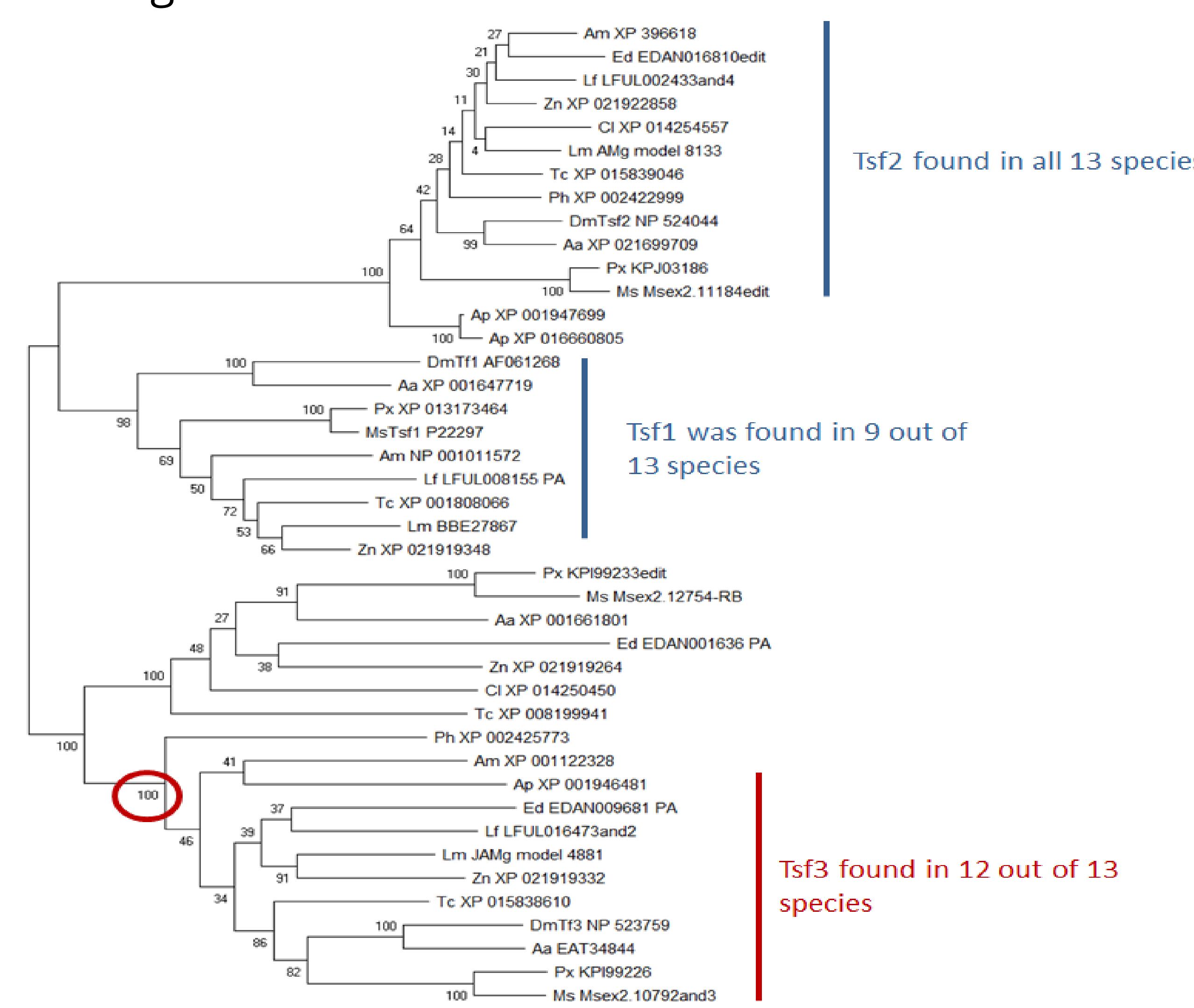

The gene cluster that contains DmTsf3 includes a sequence from all but one of the insect species analyzed. This cluster is supported by a bootstrap value of 100 therefore, it is likely that most species of insects contain Tsf3 ortholog. Orthologous proteins tend to have the same biological function; therefore, anything we learn about the function DmTsł3 has a high possibility that it applies to other insects as well.

\section{Possible Iron Uptake Pathways}

This diagram shows two possible pathways that insect cells may use to uptake the iron bound to Tsf3. Model \#1 shows the reduction of ferric ions bound to Tsf3 into through a ferrous transporter. Model \#2 shows full uptake of the iron-bound Tsf3.

Hemolymph

(insect blood)

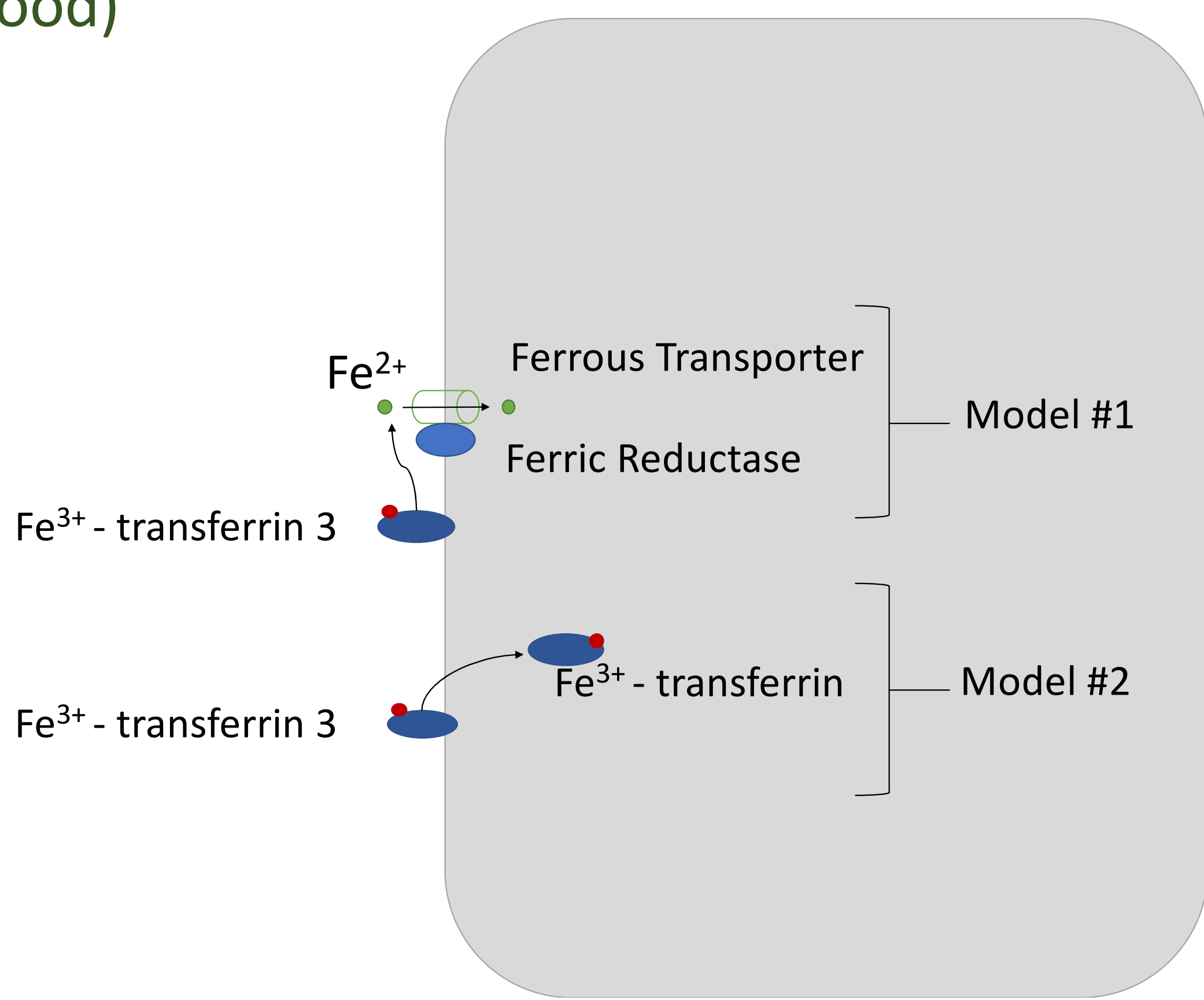

Conclusions

- Tsf3 is predicted to be an extracellular membranebound protein that can bind to iron.

The salivary glands in the white prepupae have the highest expression of Tsf3 suggesting that transferrin 3 RNAi-mediated knockdown can successfully knockdown Tsf3 in Sg4 cells.

anything we discover have a Tsf3 ortholog, which suggest apply to other insects.

Future Research

- We will be performing a ferrozine-based assay to determine if knockdown of Tsf3 has an effect on iron concentration in $\mathrm{Sg} 4$ cells.

If results from the ferrozine-based assay are positive, the next step would be to determine whether model \#1 or model \#2 is involved in the uptake of iron bound to Tsf3.

Acknowledgements

This work is supported by National Science Foundation grant . 5R25GM119968-02 to Kansas Bridges to the Future and Developing Scholars Program. We thank Kayla Wilkinson for designing the dsRNA sequence that targets Tsf3, and for synthesizing dsRNA-Tsf3 (2019) TS 3 axpression advice on the are from FlyBase Acids Res 47: D759-765). 